УДК 342.98

\title{
ИЗ ПРАКТИКИ ОСПАРИВАНИЯ НЕЗАКОННОГО НАКАЗАНИЯ В ЯРОСЛАВСКОМ ГАРНИЗОННОМ ВОЕННОМ СУДЕ
}

\author{
Размолодин Максим Львович \\ Международная академия бизнеса \\ и новых технологий (МУБиНТ) \\ г. Ярославль
}

Аннотация: В статье дается анализ причин невозможности восстановить нарушенные права и законные интересы в Ярославском гарнизонном военном суде при вынесении военнослужащим незаконных взысканий по сфальсифицированным основаниям недобросовестными должностными лицами УФСБ РФ по Ярославской области. Актуальность темы обуславливается выявлением недостатков и упущений в работе суда, которые не позволяют утверждать готовность и способность судебных органов защитить законные интересы военнослужащих, нарушенных в результате злоупотребления правом в административных отношениях.

Ключевые слова: гарнизонный военный суд, органы федеральной службы безопасности, незаконное увольнение военнослужащего, фальсификация оснований увольнения, оспаривание увольнения в военном суде, злоупотребление правом в административных отношениях.

FROM THE PRACTICE OF CHALLENGE OF ILLEGAL PUNISHMENT IN THE YAROSLAVL GARRISON COURT

\section{Razmolodin Maxim Lvovich}

\begin{abstract}
The article analyzes the reasons for the inability to restore violated rights and legitimate interests in the Yaroslavl Garrison Military Court when illegal penalties are imposed on military personnel on falsified grounds by unscrupulous officials of the Federal Security Service of the Russian Federation in the Yaroslavl region. The relevance of the topic is determined by the identification of shortcomings and the definition of omissions in the work of the court, which at this stage do not allow us to conclude about the readiness and ability of the judicial
\end{abstract}


authorities to protect the legitimate interests of military personnel violated as a result of abuse of law in administrative relations.

Keywords: garrison military court, bodies of the federal security service, illegal dismissal of a serviceman, falsification of the grounds for dismissal, challenging dismissal in a military court, abuse of law in administrative relations.

В данной статье будет рассмотрена тема судебного оспаривания незаконного взыскания с последующим увольнением военнослужащего со стороны недобросовестных должностных лиц УФСБ РФ по Ярославской области, осуществленном в форме злоупотребления правом в административных отношениях (Далее - ЗПАО), характерные черты которого уже становились объектом анализа [4].

Отметим, что проблема ЗПАО в ведомственных, правоохранительных и военных структурах приобретает все большую актуальность в связи малой эффективностью явного начальственного произвола из-за расширившихся возможностей рядовых служащих по обжалованию волюнтаристских действий руководства в административном и судебном порядках. Именно по этой причине недобросовестные должностные лица, осознавая противоправный характер своих действий при фальсификациях наказаний, вынуждены создавать жертвам искусственные препятствия для восстановления нарушенных прав в судебных инстанциях.

В этой связи интерес представляет изучение практики судебного обжалования незаконных наказаний в форме ЗПАО в целях выяснения способности и готовности российских судебных органов восстанавливать нарушенные права пострадавших от административного произвола граждан. Для этого обратимся к опыту военнослужащего УФСБ РФ по Ярославской области по оспариванию незаконного наказания в Ярославском военном гарнизонном военном суде (первая инстанция), Московском Окружном военном суде (апелляционная инстанция), Новосибирском кассационном военном суде (кассационная инстанция) и в Коллегии по делам военнослужащих Верховного суда РФ (вторая кассационная инстанция).

В 2014-2018 гг. в УФСБ РФ по Ярославской области (Далее - УФСБ или УФСБ по ЯО) прокатилась волна массовых увольнений военнослужащих по сфабрикованным основаниям, что уже находило критическое отражение как в публикациях в ИПС Интернет, так и на страницах научных изданий $[4,5,6,7]$. Инициатором незаконных увольнений являлся начальник отдела кадров 
Управления Залепухин Дмитрий Валерьевич, а фальсификацию оснований для наказаний осуществляла начальник правового подразделения Горячих Ольга Валерьевна. Нарушения прав военнослужащих проходили либо по прямому указанию начальника УФСБ Кубасова Александра Владимировича и его заместителя Огородникова Владимира Георгиевича, либо при их молчаливом попустительстве.

14 июля 2016 года Приказом начальника УФСБ РФ по Ярославской области за совершение коррупционного правонарушения, выразившегося в предоставление заведомо недостоверных и неполных сведений о доходах, расходах, об имуществе и обязательствах имущественного характера за 20132015 гг., нарушении ст. 8 Федерального закона от 25 декабря 2008 г. №273-Ф3 «О противодействии коррупции», военнослужащему был объявлен строгий выговор с последующим увольнением.

Данное взыскание было произведено в форме злоупотребления правом в административных отношениях, механика которого подробно изложена в предыдущей статье автора, и сопровождалось грубейшими нарушениями норм материального и процессуального права [4]. Незаконность наказания подтверждена экспертным заключением Министерства труда и социальной защиты РФ (№ 18/3ООГ-103 от от 28.01.2019 г.) - органом, уполномоченным Указом Президента РФ от 2 апреля 2013 г. № 309 давать трактовку Методических рекомендаций по вопросам представления сведений о доходах, расходах и обязательствах имущественного характера, а потому заявленная ведомством позиция не допускает иного толкования. В вышеуказанном ответе Минтруда РФ содержался однозначный вывод о том, что должностные лица УФСБ неверно трактовали требования Методических рекомендаций Минтруда РФ по заполнению Справок о доходах в 2013-2015 гг., из чего следовал вывод о том, что и объявленный строгий выговор, и последовавшее за ним увольнение противоречили российскому законодательству.

Умышленную фальсификацию оснований для вынесения незаконного взыскания со стороны начальника отдела кадров УФСБ Д.В. Залепухина и его пособницы О.В. Горячих подтверждает тот факт, что военнослужащим предоставлялись доказательства правомерности представленных в Декларации сведений о доходах, но указанными лицами были проигнорированы. О фабрикации оснований взыскания говорят и предпринятые фальсификаторами меры по сокрытию от военнослужащего фактической стороны правонарушения с тем, чтобы создать искусственные 
препятствия для оспаривания незаконного наказания в судебном порядке. В этих целях ими были грубо нарушены нормы ст.51.1 Ф3 №53 «О воинской обязанности и военной службе», регулирующей порядок применения взысканий за совершенные военнослужащими коррупционные правонарушения, а именно: отказ в ознакомлении военнослужащего с докладом по результатам проверки; отказ от вручения военнослужащему копии акта о совершении коррупционного правонарушения; отказ в предоставлении военнослужащему возможности дать письменные объяснения по результатам ознакомления с докладом о результатах проверки, проведенной подразделением кадровой службы.

Об умышленном лишении возможности оспорить незаконное взыскание в суде свидетельствует и грубое нарушение правил проведения аттестационной комиссии 12 июля 2016 г., с заседания которой $n p u$ заслушивании доклада по результатам проверки военнослужащий был удален, а потому был лишен возможности получить информацию о допущенных им нарушениях при заполнении Справок о доходах, что подтверждается выпиской из протокола заседания комиссии.

Важно также отметить, что в приказе о вынесении взыскания, в уведомлении по результатам проверки и в выписке из протокола заседания аттестационной комиссии УФСБ РФ по ЯО полностью отсутствовала информация о фактических обстоятельствах допущенных нарушений при заполнении Справок о доходах, что подтверждается текстом указанных документов. При этом в нарушении правил секретного делопроизводства Д.В. Залепухиным докладу был присвоен завышенный гриф секретности с тем, чтобы исключить предоставление документа военнослужащему на руки.

Здесь также следует упомянуть и об еще одном незаконном приеме, примененном фальсификаторами из УФСБ Д.В. Залепухиным и О.В. Горячих, который не становится для военных судов предметом судебного контроля. Речь идет о ненадлежащем составе аттестационных комиссий, в которые инициаторами административного произвола привлекаются зависимые и подконтрольные им лица, готовые утвердить любые абсурдные и противоречащие закону решения своих покровителей. Согласно законодательству заседание аттестационной комиссии признается легитимным в том случае, если на нем присутствовало не менее двух третей ее членов. Из общего числа членов аттестационной комиссии в 14 человек на заседание аттестационной комиссии 12.07.2016 г., выносившей решение о 
наказании военнослужащего, присутствовало 8 и отсутствовало 6 человек. Таким образом, требование законодательства РФ о кворуме в 9 человек соблюдено не было. В целях искусственного «наполнения» состава аттестационной комиссии и придания ей легитимного характера начальником отдела кадров Д.В. Залепухиным на заседание 12.07.2016 г. были приглашены лица из числа ветеранов УФСБ, которые не являлись действующими на тот момент сотрудниками ведомства и тем более членами аттестационной комиссии, в связи с чем принимать участие в заседании и голосовать за вынесение взыскания не имели права. Информацией о причинах признания Ярославским гарнизонным военным судом (Далее - ЯГВП) законными решений нелегитимных аттестационных комиссий обладает председатель суда Д.Г. Пызиков и судья ЯГВС С.В. Некрасов, которые, к сожалению, не делятся ею при оформлении судебных решений.

В результате нарушений вышеуказанных норм федерального законодательства со стороны руководства УФСБ по Ярославской области военнослужащий не смог обратиться после объявления ему приказа о вынесении взыскания в суд с административным исковым заявлением в соответствии с требованиями ст. 125 КАС, т. к. в заявлении истец должен указывать основания и доводы, обосновывающие его требования (подпункт 5 п. 2 ст.125 КАС); привести доказательства собственной невиновности (п. 4 ст. 125 КАС); предоставить документы, подтверждающие требования истца (п.3 ст.126 КАС); изложить сведения о том, какие права, свободы и законные интересы истца нарушены (подпункту 4 п.2 ст.125 КАС). Умышленность незаконных действий должностных лиц УФСБ Д.В. Залепухина и О.В. Горячих подтверждается тем обстоятельством, что на неоднократные письменные обращения военнослужащего к руководству ведомства с требованием представить для ознакомления доклад о результатах проверки, он получал неизменный отказ с формулировкой «в виду нецелесообразности».

Не обладая информацией о фактической стороне вменяемых ему правонарушений военнослужащий не мог подать административного искового заявления в суд в течение определяемого КАС трехмесячного срока после ознакомления 14 июля 2016 г. с приказом о наложении взыскания, т. к. само содержание обращения в суд выглядело бы комичным: «Мне объявлено взыскание по неизвестным основаниям. Я меня нет доказательств собственной невиновности, я не могу аргументировать свою позицию и сообщить суду какие мои права, свободы и законные интересы нарушены. На основании 
вышеизложенного прошу отменить приказ о наказании». Понятно, что участие истца без знания фактических обстоятельств правонарушения, предварительной подготовки, формирования системы аргументации и доказательств собственной невиновности означало заведомый проигрыш дела и легитимацию судебным решением незаконности, несправедливости и необоснованности наложенного взыскания, т. к. в суде был бы нарушен основополагающий принцип равноправия сторон, ибо сторона ответчика обладала бы всей полнотой информации по делу, а сторона истца даже не знала фактической стороны оспаривания, что существенно ограничивало ее возможности для самозащиты.

В целях выяснения обстоятельств, юридических фактов, доводов выносившей взыскание стороны уже уволенный военнослужащий в 2016-2018 гг. неоднократно направлял в Ярославскую гарнизонную военную прокуратуру обращения, из ответов на которые ему стала известна фактическая сторона вменяемых ему нарушений.

На основе полученной из ЯГВП информации в январе 2019 г. военнослужащий обратился в Министерство труда и социальной защиты РФ с просьбой дать правовую оценку обстоятельств, послуживших основанием для вынесения взыскания. Ответ Минтруда РФ за № 18/3ООГ-103 от 28.01.2019 г. содержал однозначный вывод о незаконности вынесенного взыскания, что дало военнослужащему право полагать о том, что он узнал о нарушении своих прав именно в феврале 2019 г. из ответов ЯГВП и экспертного заключения Минтруда РФ.

В мае 2019 г. до истечения трехмесячного срока обращения в суд в соответствии со ст.219 КАС, когда военнослужащий в феврале 2019 г. узнал о нарушении своих прав из ответов ЯГВП и Минтруда РФ, он обратился в Ярославский гарнизонный военный суд с административным исковым заявлением об отмене незаконного приказа.

18 июня 2019 г. судья Пызиков Дмитрий Геннадьевич, являющийся также председателем ЯГВС, принял решение об отказе административного иска в связи с пропуском истцом трехмесячного срока обращения в суд с заявлением об оспаривании действий должностного лица в отсутствие уважительных причин пропуска этого срока. В решении безосновательно и бездоказательно утверждалось, что о привлечении к дисциплинарной ответственности административному истцу достоверно и окончательно стало известно 14 июля 
2016 года после ознакомления с оспариваемым приказом, а потому обратиться в суд он должен был в течение трех месяцев после этой даты.

Зафиксируем, что использовавшийся недобросовестными должностными лицами УФСБ РФ по Ярославской области Д.В. Залепухиным и О.В. Горячих прием по сокрытию от жертвы административного произвола фактической стороны сфальсифицированного ими взыскания, оказался весьма успешным. Восстановить нарушенные права в Ярославском гарнизонном военном суде, возглавляемом судьей Д.Г. Пызиковым, оказалось не возможным.

Анализ решения судьи Д.Г. Пызикова показывает, что им был нарушен целый комплекс требований КАС РФ при рассмотрении дела. Отсутствие в решении суда оценки представленных истцом доказательств того, что должностными лицами УФСБ намеренно скрывалась фактическая сторона совершенного правонарушения прямо противоречит установкам КАС РФ о всестороннем, полном и объективном исследовании обстоятельств административного дела, что повлекло как неверные выводы, так и решение.

В чем же конкретно состоят допущенные судьей Д.Г. Пызиковым изъяны в судейской работе?

Во-первых, имеющееся в решении суда утверждение о пропуске истиом трехмесячного срока обращения в суд опровергается нормами российского законодательства, которые или не были известны председателю ЯГВС Д.Г. Пызикову, или намеренно им игнорировались.

Согласно статьи 219 КАС РФ административное исковое заявление может быть подано в суд в течение трех месяцев со дня, когда гражданину, организации, иному лицу стало известно о нарушении их прав, свобод и законных интересов.

Таким образом, КАС РФ устанавливает трехмесячный срок для обращения в суд именно с момента того, когда истцу стало известно о нарушении его прав, а не дату ознакомления с приказом о наказании, т. к. в противном случае об этом прямо было бы указано в законодательстве. В частности, в ст. 392 Трудового кодекса РФ (ТК РФ) определяет, что гражданин имеет право обратиться в течение одного месяца со дня вручения ему копии приказа об увольнении либо со дня выдачи трудовой книжки. Если бы законодатель хотел отождествить день, когда гражданину стало известно о нарушении его прав, и дату ознакомления с приказом о взыскании, то в КАС РФ было бы четко об этом указано, а именно: что право на обращение в суд 
наступает в течении трех месяцев с момента ознакомления гражданина с приказом о взыскании (подобно тому как этот вопрос разрешается в ТК РФ).

Очевидно, что в КАС РФ понятия дня, когда истцу стало известно о нарушении его прав, и дата ознакомления с приказом о наказании не совпадают, т. к. из норм ст.51.1 Ф3 №53 «О воинской обязанности и военной службе» момент нарушения прав гражданина наступает тогда, когда ему становятся известны конкретные обстоятельства, факты и доводы выносившей взыскание стороны, на основе которых он может составить административное заявление и оспорить взыскание в суде.

Данное утверждение подтверждается нормами КАС, устанавливающих, что в административному исковом заявлении в суд истец излагает основания и доводы своих требований (подпункт 5 п.2 ст.125 КАС); приводит имеющих значение для правильного разрешения административного дела доказательства (п. 4 ст. 125 КАС); прилагает документы, обосновывающие его требования (п.3 ст.126 КАС); излагает сведения о нарушенных правах, свободах и законных интересах (подпункту 4 п.2 ст.125 КАС).

Очевидно, что требования КАС РФ к административному исковому заявлению могли быть выполнены военнослужащим только в случае соблюдения должностными лицами УФСБ Д.В. Залепухиным и О.В. Горячих норм ст.51.1 Ф3 №53 «О воинской обязанности и военной службе» и предоставлении прилагающегося к приказу доклада по результатам проверки и копии акта о совершении военнослужащим коррупционного правонарушения (которые должны были быть вручены истцу под расписку в соответствии с п.6). Ознакомление с указанными документами, содержащими фактическую сторону правонарушения, и стало бы точкой отсчета дня, когда гражданину стало известно о нарушении его прав, что позволило бы ему в случае несогласия с результатами проверки составить административное исковое заявление в суд в соответствии с вышеназванными требованиями КАС РФ.

Но в том то и дело, что текст приказа таких сведений не содержал, а долженствующий прилагаться к приказу в соответствии со ст.51.1 Ф3 №53 «О воинской обязанности и военной службе» доклад и акт о правонарушении для ознакомления военнослужащему не предоставлялись, что судьей Д.Г. Пызиковым не было принято во внимание.

Во-вторых, содержащееся в решении судьи Д.Г.Пызикова утверждение о том, что о привлечении к дисциплинарной ответственности 
административному истцу достоверно и окончательно стало известно после ознакомления с оспариваемым приказом легко опровергается следующими фактами.

Судья Д.Г. Пызиков проигнорировал существенное для административного дела обстоятельство, что в тексте приказа о взыскании отсутствуют конкретные обстоятельства, факты и доводы выносившей взыскание стороны, а потому день ознакомления с приказом не мог являться точкой отчета дня, когда истцу стало известно о нарушении его прав. Как уже отмечалось, в соответствии с требованиями ст.51.1 Ф3 №53 «О воинской обязанности и военной службе» о нарушении своих прав военнослужащий должен был узнать из ознакомления прилагаемым к приказу докладом по результатам проверки и актом о совершении военнослужащим коррупционного правонарушения, которые от него были умышленно скрыты должностными лицами УФСБ Д.В. Залепухиным и О.В. Горячих.

В-третьих, тенденциозность и необъективность позиции судьи Д.Г. Пызикова при рассмотрении дела проявилась в игнорировании требований КАС РФ о полном, всестороннем и объективном исследовании обстоятельств и доказательств, а также отказе выполнять возложенные на суд контрольные функции.

О том, что судья Д.Г. Пызиков явно занял позицию более сильной в административном отношении стороны свидетельствует отсутствии в решении суда оценки фактов грубых нарушений должностными лицами УФСБ РФ норм ст.51.1 Ф3 №53 «О воинской обязанности и военной службе», направленных на лишение военнослужащего предоставленной законодательством РФ возможности своевременно обжаловать незаконное взыскание; игнорирование представленных истцом доказательств того, что о нарушении своих прав он узнал только в феврале 2019 г. из экспертного заключения Минтруда РФ после двухгодичной переписки с ЯГВП; незаконного состава аттестационной комиссии и, как следствие, нелегитимности решения о наложении на военнослужащего наказания. Не нашли своего отражения в решении и многочисленные отказы руководства УФСБ предоставить военнослужащему доклад для ознакомления с фактической стороной вменяемых ему правонарушений. Нежелание включать в судебное решение вышеуказанные существенные для дела обстоятельства продемонстрировало отход судьи Д.Г. Пызикова от выполнения возложенных на суд контрольных функций, т. к. при объективном подходе он был бы 
вынужден признать факты нарушений закона должностными лицами УФСБ РФ по Ярославской области и проинформировать о них центральное руководство ФСБ РФ.

В последнее время судебные органы подвергаются весьма резкой и справедливой критике со стороны российского общества. Одной из причин этого является неспособность граждан при явной правоте своей позиции отстоять нарушенные права и законные интересы не только в суде первой инстанции, но и в апелляционном, и кассационном порядках. Многочисленные факты судебного произвола, находящие отражения в СМИ и ИПС Интернет, свидетельствует о существенных сбоях в работе всей судебной системы. Не стало исключением и дело военнослужащего, который, приведя неоспоримые доводы правоты в административном споре, не нашел поддержки в Московском Окружном суде (судьи Павленок С.В. (председательствующий), Дзадзиев Д.А. и Масенин П.Е.) и Кассационном военном суде (судьи Иванов В.В. (председательствующий), Шпаков С.П. и Яковлев И.А.), вынесшие определения об оставлении без изменений решения ЯГВС, а жалобы - без удовлетворения. Судья Верховного суда РФ А.В. Воронов и вовсе отказал в передаче кассационной жалобы для рассмотрения в судебном заседании суда второй кассационной инстанции, причем Заместитель председателя Верховного суда РФ В.В. Хомчик, облеченный контрольными функциями за работой нижестоящих судей, его в этом решении поддержал.

На фоне неспособности российской судебной системы защитить граждан от административного произвола сами судьи нередко становятся источниками грубого попрания законодательства РФ. Об этом свидетельствует связанный с рассматриваемым делом факт. 18 июня 2019 г. по окончании судебного заседания истец в соответствии с ч.2 ст.207 КАС РФ подал в ЯГВС заявление об ознакомлении с протоколом судебного заседания. В соответствии с ч.3 ст.206 КАС РФ протокол должен быть составлен и подписан не позднее, чем через три дня после судебного заседания, а потому 22 июня протокол должен был быть предоставлен заявителю. По вине должностных лиц ЯГВС, в частности судьи Д.Г. Пызикова, на дату подачи 5 июля 2019 г. в Московский окружной военный суд апелляционной жалобы истца с протоколом судебного заседания не ознакомили, чем лишили возможности внести замечания и использовать документ для подготовки к суду апелляционной инстанции. Какова же была реакция Московского окружного военного суда на явное 
нарушение ч.3 ст.206 КАС РФ? По мнению судей Павленка С.В., Дзадзиева Д.А. и Масенина П.Е., нарушений судьей Д.Г. Пызиковым законодательства РФ, в частности, требований КАС РФ, не имело места быть, т. к. отказ в ознакомлении с протоколом судебного заседания не свидетельствовал о наличии препятствий для обжалования истцом решения гарнизонного военного суда, ибо фактически им таковая была подана и без ознакомления с протоколом. Проще говоря, вышестоящие судьи закрыли глаза на нарушения председателем ЯГВС Д.Г. Пызиковым федерального законодательства и прав истца.

В этой связи можно сделать вывод о формировании в России самодовлеющей судейской касты, отгородившейся от общества невиданными для других слоев общества привилегиями, в том числе гарантиями личной неприкосновенности. Попытка заимствовать западный опыт по формированию независимого суда привела к созданию в России уродливой конструкции, слабо напоминающий заграничный оригинал. Независимость суда обернулась выходом служителей Фемиды из-под контроля общества, утратившего механизмы ограничения судебного беспредела, что уже создает угрозу социальной стабильности и повышает недовольство среди лояльных существующему режиму групп населения. Законодательную норму, запрещающую сотрудниками ГИБДД пресекать управление судьей автотранспортом в состоянии алкогольного опьянения, можно расценивать как правовое санкционирование на убийство судьями сограждан. Деятельность судейской касты регулируется уже не столько законодательством РФ, сколько только ей известными законами, круговой порукой и двойными стандартами, когда за однотипные правонарушения простые граждане РФ несут ответственность по всей строгости закона, а служители Фемиды, где судьями выступают их же коллеги, - никакой.

Для наглядности приведем пример из практики. В данной статье описана ситуация, когда по сфабрикованному основанию о якобы предоставлении недостоверных сведений о доходах военнослужащий не только был несправедливо уволен, но и не смог восстановить нарушенные права в процессе, который вел судья Д.Г. Пызиков. При рассмотрении 21 ноября 2016 г. Высшей квалификационной коллегией судей РФ кандидатуры Д.Г. Пызикова на должность председателя Ярославского гарнизонного военного суда выяснилось, что вышеозначенный служитель Фемиды скрыл в анкете претендента факты привлечения к административной ответственности за 
нарушение правил дорожного движения и неоднократное привлечение брата супруги к уголовной ответственности. Подвергся ли судья Д.Г. Пызиков осуждению коллег за утаивание сомнительных фактов биографии, которые выяснились в ходе проверки? Нет. Мало того, Высшая квалификационная коллегия судей РФ посчитала, что предоставление претендентом недостоверных сведений не является основанием для отказа в рекомендации на занятие высокой должности. Что это как не пример двойных стандартов, ставших для судейского сообщества повседневной нормой?

Оборотной стороной снисходительного отношения судейской касты к нарушениям закона своих членов является предельная жесткость к пытающимся найти справедливость гражданам их числа простолюдинов. Анализ решений Ярославского гарнизонного военного суда в 2012-2019 гг. показывает, что из 30 рассмотренных судом дел по административным искам военнослужащих территориальных Управлений ФСБ РФ в связи с нарушениями их прав и оспариванию произвола руководства ни одно не было удовлетворено в связи с наложением незаконных взысканий и увольнениями. В таких условиях у военнослужащих органов ФСБ РФ сформировалось обоснованное мнение о невозможности защитить свои нарушенные права в Ярославском гарнизонном суде, а потому из около десяти (!!!) уволенных сотрудников Ярославского УФСБ РФ в 2015-2018 гг. в результате вынесения взысканий лишь двое обратились за защитой в ЯГВС и ожидаемо не нашли удовлетворения своих требований, в очередной раз подтвердив сложившееся мнение о тенденциозности и необъективности Ярославского военного суда.

Пройдет время и по старой российской традиции нынешний период истории страны подвергнется очередному осуждению неожиданно прозревшим обществом. Нет сомнения в том, что в учебниках истории в качестве постыдных явлений современной жизни будут названы произвол, безответственность и вседозволенность служителей Фемиды. Опыт разоблачения сталинских репрессий свидетельствует, что ни доносчики, ни фабриковавшие уголовные дела следователи, ни выносившие несправедливые приговоры судьи не были привлечены к персональной ответственности за массовый террор против соотечественников. Можно утверждать, что в порыве будущих разоблачений ни один из ныне причастных к правовому беспределу судей не понесет даже морального наказания перед обществом. Вся вина в очередной раз будет возложена на одного человека, ныне возглавляющего российское государство, ему одному (как и Сталину) припишут грехи тех, кто 
прикрываясь законом творил беззаконие. Не исключено, что носящие судейские мантии лица, чьи имена прозвучали в данной статье, встанут в первых рядах критиков и обличителей порочной судебной системы, с которой они якобы боролись, но вынуждены были подчиняться перед силой непреодолимых обстоятельств.

Есть ли выход из создавшегося положения? Обращения с жалобами в органы исполнительной, законодательной и судебной власти не дают результатов. Ставшие повседневной нормой российской реальности чиновничьи отписки свидетельствуют о том, что должностные лица всех уровней остаются глухи к запросу общества о наведении порядка в деятельности судов. Представляется, что единственным путем борьбы за справедливое правосудие является предание огласке фактов судебного произвола через средства массовой информации и ИПС Интернет, где пока сохраняются относительные свободы на выражение независимого мнения. Но долго ли право на свободу слова будет сохраняться, если уже сейчас Верховный суд РФ вносит в ГД РФ предложения о запрете в СМИ критики деятельности судебной корпорации?

\section{Список литературы}

1. Ф3 №53 «О воинской обязанности и военной службе» // СПС КонсультантПлюс (дата обращения: 10.03.2021);

Указ Президента РФ от 2 апреля 2013г. N309 «О мерах по реализации отдельных положений Федерального закона "О противодействии коррупции"» // СПС КонсультантПлюс (дата обращения: 06.03.2020);

3. Кодекс административного судопроизводства Российской Федерации // СПС КонсультантПлюс (дата обращения: 12.03.2021).

4. Размолодин М.Л. О злоупотреблении правом должностными лицами при наложении наказаний на военнослужащих (на примере УФСБ РФ по Ярославской области) // Правовая система России: История и современность: Сборник статей Международной научно-практической конференции (1 октября 2019 г, г. Пермь). - Уфа: Аэтерна, 2019. С.15-38.

5. Размолодин М.Л. О проблемах защиты прав военнослужащих в гарнизонных военных судах (на примере Ярославского гарнизонного военного суда) [Текст] / М.Л. Размолодин // Сборник статей Международной научно-практической конференции «Верховенство права: международный и 
национальный аспект» (Челябинск, 14.11.2020 г.). - Стерлитамак: АМИ, 2020. - C. 83-90.

6. Размолодин М.Л. О недостатках работы органов военной прокуратуры по защите прав военнослужащих (на примере Ярославской гарнизонной военной прокуратуры) // NEW CHALLENGES IN NEW SCIENCE : сборник статей Международной научно-практической конференции (25 ноября 2020 г.). - Петрозаводск : МЦНП «Новая наука», 2020.С. 219-218.

7. Размолодин М.Л. Из практики судебного обжалования бездействия органов военной прокуратуры на нарушения прав военнослужащих (на примере Кировского суда г.Ярославля) // Высшая школа: научные исследования. Материалы Межвузовский международный конгресс (г. Москва, 4 марта 2021 г.). - Москва: Издательство Инфинити, 2021. С. 30-40.

8. Размолодин М.Л. О проблемах оспаривания в органах военной прокуратуры незаконных взысканий за коррупционные правонарушения (на примере УФСБ РФ по Ярославской области и Ярославской гарнизонной военной прокуратуры) // Юриспруденция в теории и на практике: вопросы совершенствования правовой грамотности: Сборник статей Международной научно-практической конференции (1 декабря 2019 г, г. Воронеж). - Уфа: Аэтерна, 2019. С. 58-73.

(C) М.Л. Размолодин 